\title{
CRITICAL SUCCESS FACTOR OF PRIVATIZATION PROJECT
}

\author{
Mohd Nadzri Jaafar ${ }^{1}$, Azizah Ismail ${ }^{*}$, Mat Naim Abdullah ${ }^{3}$, Mohd Asmoni $^{4}$, \\ Musyirah Abdullah ${ }^{5}$ \\ 1,2,3,4,5Faculty of Built Environment and Surveying, Universiti Teknologi Malaysia, \\ Skudai, Johor Bahru, Malaysia.
}

*Corresponding Email: azizahismail@utm.my

\begin{abstract}
Privatization is generally defined as the transfer of activity and function, particularly in the area of infrastructure development for the purpose of improving management efficiency, productivity as well as ensuring economic growth in tandem with the vision 2020. Although the privatization of certain property development projects has been successfully implemented, there are still a number of abandoned projects and the reasons for success are not fully explained. In Johor, there has been no study on the success factors of the privatization project for commercial buildings. Therefore, the objective of this study is to define critical success factors for privatized development projects and to identify developers' characteristics that affect the success factor of a privatization project by identify the successful privatization projects and selected 3 successful privatized commercial privatization projects. Furthermore, the characteristics of developers affecting the success of the project will be identified to facilitate the Johor State Economic Planning Division to identify the criteria of the developer to the project which has the potential of a successful privatization project.
\end{abstract}

Keywords: Critical Success Factor, Privatization Project, Commercial Project, Developer's Criteria, Success Criteria.

\section{Introduction}

The recession in the early 1980s had affected the government's ability to finance the country's development program and had forced the government to re-coordinate public sector spending. In line with the rapid expansion of the public sector around the world in the mid-1980s, Malaysia is no exception in taking the same steps. The Government has identified, selected and surrendered several public service providers to the private sector with the aim of reducing the involvement of the government in the economic sector while at the same time mitigating the country's financial burden through the Malaysian Privatization Master Plan (PMP) in 1991 followed by the Privatization Guidelines. Among the approaches that have been used by the government to privatize its public sector are, sell out shares, lease, sell-shares, BOT (build-owntransfer), corporatization and other forms yet (Private Public Co-operation Unit, 2015). the critical factor that led to the development of the privatization concept was due to the performance weakness shown by government corporations.

\section{Privatization in Malaysia}

In Malaysia, privatization was first introduced in March 1983 by then prime minister Tun Dr Mahathir Mohamad, seen as giving such functions to governments in developed countries. It aims to reduce the level and scope of public spending and enable the market to form the economy of the State. PPP or privatization was introduced during the mid-4th Malaysia Plan and later in 1983, Privatization Policy In 1983, Privatization Guidelines 1985. Since independence in 1957 ten Malaysia Plans have been planned to bring Malaysia to a more developed one. Private Public Partnership (PPP) in Malaysia is divided into 3 namely privatization, Private Finance Initiative (PFI) and Private Public Partnership (PPP). Privatization Policy 1983 was issued followed by the 1985 Privatization Guidelines and Privatization 1991. The Private Finance Initiative (PFI) began with the 2006 Treasury Guidelines and for the Private Public Partnership (PPP) UKAS Guidelines in 2009 and the New Wave of Public Private Partnerships (PPP) in 2010. The Privatization Policy is introduced by having the following objectives:

- Reducing Government Finance Loans

- Improve Efficiency and Job Creation 
- Raising Efficiency and Job Creation

- Distribution of Resources and Efficiency

- Accelerate the achievement of the Basic Aims

\section{Critical Success Factor}

Several research and case studies, also have been conducted to investigate the factors contributing to the success of PPP projects as well as the stakeholders' objectives, among them are $\mathrm{Ng}$ et al. [1]; Zhang (2006); Qiao et al. [3]; Jefferies et al. [4]; Yuan et al. [5]. A large number of such studies categorized and assessed critical success factors (CSFs) in different countries, such as UK [6], China (Chan et al., 2010; 8], Hong Kong [1], and Lithuania (Gudienè et al., 2013). Liu, Wang, \& Wilkinson [10] concluded that the success of a development project depends on the quality of the short project, the public sector capability, the governance structure, the level of competition in the tender process and the level of transparency in the tender process. Hodge and Greve (2007) in Charles Nnason Adighibe, 2015) states that no meta-analysis or statistic can actually comment on or evaluate a PPP project's performance, as it is complicated to evaluate the infrastructure of compounded observations and various contracts the arrangement of Khairuddin (Rashid, 2012; 2012a; 2012b)

Table 1 The critical success factors and their subordinate success factors from literature.

*Sources have not necessarily used completely similar phrases

\begin{tabular}{|c|c|c|}
\hline $\begin{array}{l}\text { Critical Success } \\
\text { Factor }\end{array}$ & Success Factor & References \\
\hline $\begin{array}{l}\text { 1. Legal support and } \\
\text { Encouraging } \\
\text { politics }\end{array}$ & $\begin{array}{l}\text { a) Complete guidelines } \\
\text { b) Good control } \\
\text { c) Abide by the contract of agreement } \\
\text { d) Compliance control during the } \\
\text { privatization project } \\
\text { e) Level of transparency in the privatization } \\
\text { process } \\
\text { f) Stable political system and support }\end{array}$ & $\begin{array}{l}{[4]} \\
{[13]} \\
{[3]} \\
{[6]} \\
{[14]} \\
{[15]}\end{array}$ \\
\hline $\begin{array}{l}\text { 2. Promoting social } \\
\text { support }\end{array}$ & $\begin{array}{l}\text { a) The project is environmentally } \\
\text { sustainable } \\
\text { b) Acceptance and support from the } \\
\text { community } \\
\text { c) Solve the problem of surrounding people } \\
\text { d) Benefit locals } \\
\text { e) Meets the demands and capabilities of the } \\
\text { population } \\
\text { f) Scale of projects suitable for local socio- } \\
\text { economy } \\
\text { g) Project creates job opportunities for the } \\
\text { people } \\
\text { h) Project gives investment opportunities to } \\
\text { the people } \\
\text { i) Project creates business opportunities for } \\
\text { the people } \\
\text { j) Takes into account social responsibility } \\
\text { and public interest. }\end{array}$ & $\begin{array}{l}{[14]} \\
{[1]} \\
{[16]} \\
{[17]} \\
{[18]}\end{array}$ \\
\hline $\begin{array}{l}\text { 3. Stable macro- } \\
\text { economics }\end{array}$ & $\begin{array}{l}\text { a) Stable economic condition } \\
\text { b) The ability to deal with interest rate / } \\
\text { exchange fluctuations }\end{array}$ & $\begin{array}{l}{[3]} \\
{[8]}\end{array}$ \\
\hline $\begin{array}{l}\text { 4. Financial market } \\
\text { conditions }\end{array}$ & $\begin{array}{l}\text { a) There is a long-term debt financing that } \\
\text { minimizes the risk of refinancing } \\
\text { b) Mature and available local financial } \\
\text { markets }\end{array}$ & $\begin{array}{l}{[3]} \\
{[8]}\end{array}$ \\
\hline
\end{tabular}




\begin{tabular}{|c|c|c|c|c|}
\hline 5. & $\begin{array}{l}\text { Procurement of } \\
\text { equipment / labor }\end{array}$ & a) & $\begin{array}{l}\text { Procurement capability of specialist } \\
\text { workers for the private sector } \\
\text { Ability to acquire equipment on site }\end{array}$ & $\begin{array}{l}{[4]} \\
{[3]} \\
{[19]} \\
{[17]} \\
\end{array}$ \\
\hline 6. & $\begin{array}{l}\text { Guarantee and } \\
\text { government } \\
\text { experience }\end{array}$ & a) & $\begin{array}{l}\text { The availability of government } \\
\text { experience in packing similar projects } \\
\text { Match government and long-term } \\
\text { strategic objectives } \\
\text { Guarantee / support and support from the } \\
\text { government }\end{array}$ & $\begin{array}{l}{[4]} \\
{[3]} \\
{[16]} \\
{[20]}\end{array}$ \\
\hline 7. & $\begin{array}{l}\text { Good and strong } \\
\text { partnership }\end{array}$ & $\begin{array}{l}\text { f) } \\
\text { g) } \\
\text { h) }\end{array}$ & $\begin{array}{l}\text { Careful management } \\
\text { Good compatibility , relationship } \\
\text { between the two parties } \\
\text { Simple project and clear design } \\
\text { development } \\
\text { Detailed project planning } \\
\text { Commitment and responsibility of both } \\
\text { parties } \\
\text { Open and continuous communication } \\
\text { Clarity of roles and responsibilities of } \\
\text { both parties } \\
\text { Trust }\end{array}$ & $\begin{array}{l}{[21]} \\
{[22]} \\
{[23]} \\
{[16]} \\
{[17]}\end{array}$ \\
\hline 8. & $\begin{array}{l}\text { Strong private } \\
\text { consortium }\end{array}$ & $\begin{array}{l}\text { a) } \\
\text { b) } \\
\text { c) } \\
\text { d) } \\
\text { e) } \\
\text { f) } \\
\text { g) } \\
\text { h) } \\
\text { i) } \\
\text { j) } \\
\text { k) }\end{array}$ & $\begin{array}{l}\text { Strong organizational structure } \\
\text { Objective and objective goals } \\
\text { Good leadership and entrepreneurial } \\
\text { skills } \\
\text { Experience in privatization projects } \\
\text { Strong financial position of the company } \\
\text { Appropriate allocation and risk sharing } \\
\text { Resources of management and technical } \\
\text { expertise } \\
\text { The choice of a specialist contractor } \\
\text { Efficiency in project management } \\
\text { Staff support and commitment to the } \\
\text { project } \\
\text { Scale of the project is in line with the } \\
\text { company's ability }\end{array}$ & $\begin{array}{l}{[3]} \\
{[1]} \\
{[14]} \\
{[24]}\end{array}$ \\
\hline
\end{tabular}

\subsection{Data Collection Methodologies and Analysis}

The 8 CSFs AND 44SFs were included in a questionnaire survey instrument that also addressed wider issues involved in privatization projects in the Johor. The complete questionnaire comprised three parts: questions about the respondents' individual and organizational backgrounds; issues about PPP/PFI projects, including questions about CSFs; and suggestion towards improvement of privatization projects. Opinions emanating from respondents' direct experiences were sought. This paper presents an analysis of the survey response data relating to the perceived relative importance of a catalogue of 8 CSFs for privatization projects. The questionnaire was distributed to the both public and private sector that directly involved on the privatization projects which include Department Of Valuation And Property Management, Local Authority, State Treasury Department, State Economic Planning Division on private sector and 3 developers of those successful commercial project on private sector. With the total of 31 respondent and 10 interviewee all objective has been achieved. The method to be used in this study is to use the mean value analysis (descriptive analysis) and Multi-Dimensional Scaling (MDS). The data for this analysis is comprised of raw data i.e. data received through feedback from respondents obtained through questionnaire. 


\section{Results}

The result of interview session, most of the interviewee agreed that stating a good financial position is a feature of the developers that will be highlighted in advance as it is based on previous experience, many privately owned development projects are unavoidable or inadequate in due time due to lack of capital. The expert's expertise is also a good developer feature where the privatization project at BPENJ involves many people so experienced and expert developers will be picked up first compared to other developers. A responsible and non-profit developer solely. High commitment and competitive. Developers who are compliant to every detail of the Privatization Agreement, developers who are in compliance with government policies, prioritize the needs of the people. Careful management and authoritative and honest developers. Table 2 above shows the result of descriptive analysis:

Table 2 Descriptive Analysis Result

\begin{tabular}{|c|c|c|c|}
\hline Success Factor & Sum & $\begin{array}{l}\text { Mean } \\
\text { Score }\end{array}$ & Rank \\
\hline Strong organizational structure & 140 & 4.52 & 1 \\
\hline Careful planning and management & 139 & 4.48 & 2 \\
\hline Comply with contract agreement & 137 & 4.42 & 3 \\
\hline Sources of management and technical expertise & 136 & 4.39 & 4 \\
\hline A strong corporate financial position & 136 & 4.39 & 4 \\
\hline Experience in privatization projects & 136 & 4.39 & 4 \\
\hline Commitment and responsibility of both parties & 136 & 4.39 & 4 \\
\hline compliance control during the privatization project & 136 & 4.39 & 4 \\
\hline Open and continuous communication & 135 & 4.35 & 5 \\
\hline Detailed project planning & 135 & 4.35 & 5 \\
\hline Complete guidelines & 135 & 4.35 & 5 \\
\hline Trust & 135 & 4.35 & 5 \\
\hline The clarity of roles and responsibilities of both parties & 135 & 4.35 & 5 \\
\hline Clear goals and goals & 135 & 4.35 & 5 \\
\hline The scale of the project is in line with the company's ability & 134 & 4.32 & 6 \\
\hline Stable economic conditions & 134 & 4.32 & 6 \\
\hline Good control / good conduct & 134 & 4.32 & 6 \\
\hline Project scale suitable to local socio-economy & 134 & 4.32 & 6 \\
\hline Acceptance and support from the community & 133 & 4.29 & 7 \\
\hline Staff support and commitment to the project & 133 & 4.29 & 7 \\
\hline Capacity acquisition of specialist workers for the private sector & 133 & 4.29 & 7 \\
\hline Capacity acquisition of specialist workers for the private sector & 133 & 4.29 & 7 \\
\hline $\begin{array}{l}\text { There is a long-term debt financing that minimizes the risk of } \\
\text { refinancing }\end{array}$ & 133 & 4.29 & 7 \\
\hline Capacity acquisition of specialist workers for the private sector & 133 & 4.29 & 7 \\
\hline Solve the problems of the surrounding people & 133 & 4.29 & 7 \\
\hline Stable system and political support & 132 & 4.26 & 7 \\
\hline Short project and clear design development & 132 & 4.26 & 7 \\
\hline Ability to acquire equipment on site & 132 & 4.26 & 7 \\
\hline Take into account social responsibility and public interest. & 132 & 4.26 & 7 \\
\hline The project creates job opportunities for the people & 132 & 4.26 & 7 \\
\hline Efficiency in project management & 132 & 4.26 & 7 \\
\hline Matching government and long-term strategic objectives & 132 & 4.26 & 7 \\
\hline Availability of government experience in packing similar projects & 132 & 4.26 & 7 \\
\hline Mature and available local financial markets & 132 & 4.26 & 7 \\
\hline
\end{tabular}




\begin{tabular}{lccc}
\hline Good leadership and entrepreneurial skills & 131 & 4.23 & 8 \\
\hline Expert selection of specialist contractors & 131 & 4.23 & 8 \\
\hline Appropriate risk allocation and sharing & 130 & 4.19 & 9 \\
\hline The project is environmentally sustainable & 130 & 4.19 & 9 \\
\hline The project creates business opportunities for the people & 129 & 4.16 & 10 \\
\hline Guarantee / support and Support from the government & 129 & 4.16 & 10 \\
\hline The project creates investment opportunities for the people & 128 & 4.13 & 11 \\
\hline Transparency level in the privatization process & 127 & 4.1 & 12 \\
\hline Compatibility / Good relationship between both parties & 123 & 3.97 & 13 \\
\hline Benefits the locals & 119 & 3.84 & 14 \\
\hline
\end{tabular}

Table 2 above, the analysis shows the results of the min score analysis of the factors that influence the success of the privatization development project. The results showed that the highest average score of 4.52 was that strong organizational structure was one of the main factors affecting the success of the privatization project and followed by the careful management factor of both government and private parties with an average score of 4.48 . Orderly and thorough management can launch and accelerate the process of construction of the privatization project. Furthermore, developers who comply with all agreed upon terms of the contract may affect the success of the project with an average score of 4.42. Next, with the same average score of 4.39 factors such as resources of management and technical expertise, strong corporate financial standing, experience in privatization projects. the commitment and responsibility of both parties and the control of compliance during the privatization project have also been shown to have a significant influence on the success of the privatization project.
With the lowest average score of 3.84 and 3.97, social support factors that meet the demands and capabilities of the population and good compatibility / relationship between the two parties proved by meeting the demands and capabilities of the population did not result in a successful project and achieved the real objective of the privatization project . Respondents from various backgrounds agree that these two two most important factors are from CSF2 which is a social support that encourages the role of society at the very least play an important role in the success of the privatization project.

To reinforce the argument and analysis, will be using multidimensional scale analysis (MDS). The results obtained will be seen based on $\mathrm{x}$ axis and $\mathrm{y}$ axis. Furthermore, by using this MDS analysis, the writer can see the respondents' views through two different views in evaluating the same object. The 2-dimensional value above will describe the object to 2 perspectives that can be generally said that respondents are divided into large group as shown in Figure 1.

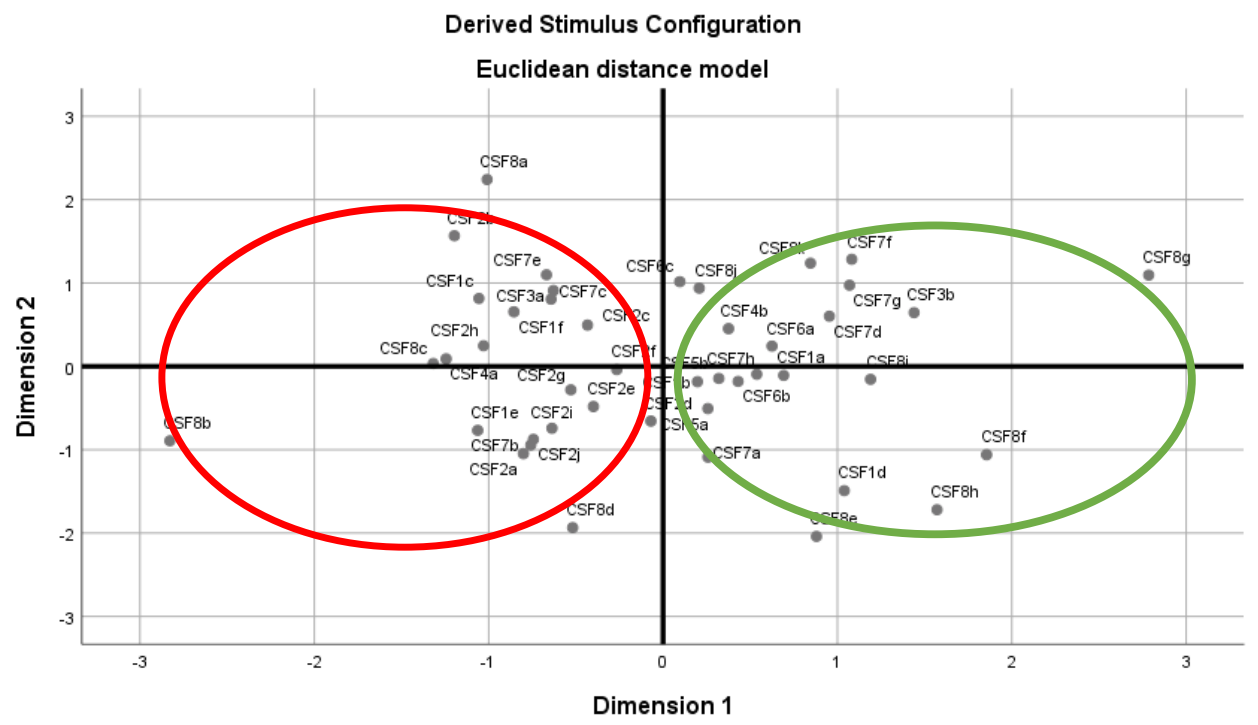

Figure 1 MDS Analysis 
Outputs obtained should be arranged according to the priority of positive value to negative value. Positive values symbolize positive effects while negative values illustrate the negative effects on a particular subject. For values close to 0 , it is likely not to have any effect on the subject. Figure illustrates the different perceptions on respondents of factors that can influence the success of privatized development projects. The first group is a variable or factors that greatly affect respondents and consist of the following factors.

Table 3 Main Factor of Successful Privatization Project

\begin{tabular}{llcc}
\hline & Main Factor of Successful Privatization Project & Dimension 1 & Dimension 2 \\
\hline CSF8e & Strong financial position of the company & 2.7851 & 1.0948 \\
\hline CSF3b & The ability to deal with interest rate / fluctuations & 1.4393 & 0.644 \\
\hline CSF7d & Detailed project planning & 1.0819 & 1.2842 \\
\hline CSF8b & Clear objective and goals & 1.069 & 0.9725 \\
\hline CSF8g & Resources of management and technical expertise & 0.9534 & 0.6014 \\
\hline CSF7e & Commitment and responsibility of both parties & 0.8453 & 1.2375 \\
\hline CSF7g & Clarity of roles and responsibilities of both parties & 0.6245 & 0.2429 \\
\hline CSF2b & Acceptance and support from the community & 0.3751 & 0.4524 \\
\hline CSF8a & Strong organizational structure & 0.2069 & 0.9388 \\
\hline CSF7h & Trust & 0.0957 & 1.0163 \\
\hline CSF7c & Simple project and clear design development & 0.2567 & -0.5064 \\
\hline CSF2c & Solve the problem of surrounding people & 0.197 & -0.1838 \\
\hline CSF7a & Careful management & 1.1898 & -0.1559 \\
\hline CSF8i & Efficiency in project management & 0.3196 & -0.1453 \\
\hline CSF7f & Open and continuous communication & 0.6917 & -0.1087 \\
\hline CSF8f & Appropriate allocation and risk sharing & 0.5373 & -0.095 \\
\hline CSF3a & Stable economic condition & 0.4302 & -0.1808 \\
\hline CSF8c & Good leadership and entrepreneurial skills & 1.0391 & -1.4912 \\
\hline CSF8d & Experience in privatization projects & 0.2573 & -1.0889 \\
\hline CSF2i & Project creates business opportunities for the people & 1.8553 & -1.0596 \\
\hline CSF2e & Meets the demands and capabilities of the population & 1.5708 & -1.7198 \\
\hline CSF2a & The project is environmentally sustainable & 0.8797 & -2.0402 \\
\hline & & & \\
\hline
\end{tabular}

Table 4 Side Factor of Successful Privatization Project

\begin{tabular}{llcc}
\hline & Side Factor of Successful Privatization Project & Dimension 1 & Dimension 2 \\
\hline CSF1d & Compliance control during the privatization project & -1.0095 & 2.2412 \\
\hline CSF1f & Stable political system and support & -0.6686 & 1.098 \\
\hline CSF4a & $\begin{array}{l}\text { Long-term debt financing that minimizes the risk of } \\
\text { refinancing }\end{array}$ & -1.197 & 1.5662 \\
\hline CSF8h & Selection of specialist subcontractors & -0.4335 & 0.4952 \\
\hline CSF5a & Procurement capability of specialist workers & -0.6293 & 0.9095 \\
\hline CSF2f & Scale of projects suitable for local socio-economy & -0.8556 & 0.6538 \\
\hline CSF8k & The scale of the project is in line with the company's ability & -1.0298 & 0.2467 \\
\hline CSF6a & $\begin{array}{l}\text { The availability of government experience in similar } \\
\text { projects }\end{array}$ & -1.0561 & 0.8148 \\
\hline CSF1c & Abide by the contract of agreement & -1.2443 & 0.0897 \\
\hline CSF8j & Staff support and commitment to the project & -1.3183 & 0.0344 \\
\hline
\end{tabular}




\begin{tabular}{llll}
\hline CSF6b & Match government and long-term strategic objectives & -0.6424 & 0.806 \\
\hline CSF4b & Mature and available local financial markets & -0.2657 & -0.0397 \\
\hline CSF1b & Good control & -0.3997 & -0.4822 \\
\hline CSF6c & Guarantee / support and support from the government & -0.5187 & -1.9351 \\
\hline CSF5b & Ability to acquire equipment on site & -0.5291 & -0.2815 \\
\hline CSF1a & Complete guidelines & -0.6373 & -0.7427 \\
\hline CSF2j & Takes into account social responsibility and public interest & -1.0632 & -0.7679 \\
\hline CSF2g & Project creates job opportunities for the people & -0.701 & -0.6567 \\
\hline CSF2h & Project gives investment opportunities to the people & 0.7441 & -0.8753 \\
\hline CSF7b & Detailed project planning & -0.7588 & -0.9438 \\
\hline CSF1e & Level of transparency in the privatization process & -0.8009 & -1.0463 \\
\hline
\end{tabular}

Based on Table 3 above, among the factors that greatly affected the success of the privatization project were the strong financial position of the company. Stable and capable financial management is a feature of developers that can have a great impact on the success of privatization projects. This is because having most companies suffer losses and negative cash flows during their initial period. Companies must ensure that they have enough cash to pay employees and suppliers even if they have more money coming out of the beginning of the business. As businesses grow and mature, they need more money to finance their growth. Planning and budgeting for financial needs are important. Financial management is looking for the appropriate source of funds at the lowest cost, controlling the company's capital costs and not allowing the balance sheet to be too high with debt with adverse effects from its credit rating as well as the curriculum should think about the profit distribution and in-kind cash and in-kind should be received by the public sector as a benefit from the privatization projects. Then followed by the ability to deal with the fluctuation of interest rates / exchange that is the ability of the project to survive in the exchange of financial mechanisms.

There are several criteria that are the side factors that influence the success of the privatization project. Table 4 above is a side-byside factor affecting the success of privatization development projects from various background respondents. Among the side factors seen at least affecting the success of the privatization project is CSF1e which is the level of sincerity in the privatization process. As is known, many developers in the market are not sincere when applying for a privatization project such as manipulating the financial statements and balances statements. Compatibility / good relationship between both sides of the CSF7b has a negative value from both sides of the dimension indicating that the relationship does not exist. The project creates investment opportunities for the people, projects generating investment opportunities to the people and considering social responsibility and public interest are all factors of CSF2 suggesting that favorable social support is the least contributing factor to the success of the project.

\section{Conclusions}

The success factor of the commercial privatization project mostly comes from the private consortium itself, as the company's strong financial position and strong organizational structure prove that it is a major factor influencing successful projects. The least successful factor mostly comes from legal support and promotes politics, financial market conditions and guarantees and governance experience shows that external factors do not really affect the success of the privatization project. Successful developers are strong financial conditions, smart financial management, expertise and experienced developers who have good track records and committed and competitive developers. Since almost all success factors from the SF8 level are high at objective 1 , the result of objective 2 has shown that a strong private consortium is very important in determining the success factor of the privatization project.

\section{References}

[1] Ng, S. T., Wong, Y. M. W., \& Wong, J. M. W. (2012). Factors influencing the success of PPP at feasibility stage e A tripartite comparison study in Hong Kong. Habitat International, $\quad 36(4), \quad 423-432$. 
https://doi.org/10.1016/j.habitatint.2012.02. $\underline{002}$

[2] Zhang X. (2006). Public Clients' Best Value Perspectives of Public Private Partnerships in Infrastructure Development. Journal of Construction Engineering and Management 132 (2) DOI:10.1061/(ASCE)07339364(2006)132:2(107)

[3] Qiao, L., Wang, S. Q., Tiong, R. L. K., \& Chan, T.-S. (2001). Framework for Critical Success Factors of BOT Projects in China. The Journal of Structured Finance, 7(1), 5361. https://doi.org/10.3905/jsf.2001.320244

[4] Jefferies, M., Gameson, R. O. D., \& Rowlinson, S. (2006). Engineering, Construction and Architectural Management Article information: To cite this document: Users who downloaded this article also downloaded : About Emerald www.emeraldinsight.com Critical success factors of the BOOT procurement system : reflec.

https://doi.org/http://dx.doi.org/10.1108/eb0 $\underline{21056}$

[5] Yuan Y., Tu Z. (2014). Critical Success Factors Analysis on Effective Information Security Management: A Literature Review. In $20^{\text {th }}$ Americas Conference on Information System, AMCIS 2014, Savannah, Georgia USA August 7-9,2014.

[6] Li, B., Akintoye, A., Edwards, P. J., \& Hardcastle, C. (2005). Critical success factors for PPP/PFI projects in the UK construction industry. Construction Management and Economics, 23(5), 459471.

https://doi.org/10.1080/0144619050004153 $\underline{7}$

[7] Chan, D.W.M., Chan, A.P.C. and Choi, T.N.Y. (2010), "An empirical survey of the benefits of implementing Pay for Safety Scheme (PFSS) in the Hong Kong construction industry", Journal of Safety Research, Vol. 41 No. 5, pp. 433-443.

[8] Tang, L. Y., Shen, Q., \& Cheng, E. W. L. (2010). A review of studies on PublicPrivate Partnership projects in the construction industry. International Journal of Project Management, 28(7), 683-694. https://doi.org/10.1016/j.ijproman.2009.11. $\underline{009}$

[9] Gudienè, N., Banaitis, A., Banaitienè, N. 2013. Evaluation of critical success factors for construction projects - an empirical study in Lithuania, International Journal of Strategic Property Management, 17(1): 2130. Article in press.
[10] Liu, T., Wang, Y., \& Wilkinson, S. (2016). Identifying critical factors affecting the effectiveness and efficiency of tendering processes in Public-Private Partnerships (PPPs): A comparative analysis of Australia and China. International Journal of Project Management, 34(4), 701-716. https://doi.org/10.1016/j.ijproman.2016.01. $\underline{004}$

[11] Charles N., A. (2015). Public Private Partnership Infrastructure Delivery: Benefits and Costs for Society. Science and Engineering Faculty. Queensland University of Technology

[12] Khairuddin A., R. (2012a). "Public Private Partnership PPP Proceedings, $4^{\text {th }}$ Malaysian Construction Summit, Kuala Lumpur, Februari 6,2012

Khairuddin A., R. (2012b). "Understanding Malaysia's PPP in G.M. Winch, M. Onishi, and S. Schmidt (eds) Taking Stock of PPP \& PFI Around the World. London: Certified Accountants Educational Trust,pp. 75-79

[13] Tingting Liu, (2016). Identifying Critical Factors Affecting The Effectiveness and Efficiency of Tendering Processes in PublicPrivate Partnerships (PPPs): A Comparative analysis of Australia and China. International Journal of Project Management 34(4):701-716. May 2016. DOI: 10.1016/j.ijproman.2016.01.004

[14] Li, B., Akintoye, A., Corresponding, P. J. E., Hardcastle, C., (2007). Critical success factors for PPP / PFI projects in the UK construction industry Critical success factors for PPP / PFI projects in the UK construction industry, 6193. https://doi.org/10.1080/0144619050004153 7

[15] Grimsey, D., \& Lewis, M. K. (2002). Evaluating the risks of public private partnerships for infrastructure projects. International Journal of Project Management, $20 \quad$ (2), 107-118. https://doi.org/10.1016/S02637863(00)0004 $\underline{0-5}$

[16] Abadi, A. A., \& Heravi, G. (2019). The effect of critical success factors on project success in Public-Private Partnership projects: A case study of highway projects in Iran. Transport Policy, 73 (July 2017),152161.

https://doi.org/10.1016/j.tranpol.2018.07.00 4

[17] Osei-kyei, R., \& Chan, A. P. C. (2015). ScienceDirect Review of studies on the Critical Success Factors for Public - Private Partnership ( PPP ) projects from 1990 to 
2013. JPMA, 33(6), 1335-1346. https://doi.org/10.1016/j.ijproman.2015.02. 008

[18] Hariss P., Mbugua L. M., Holt G. D. (2016) A Framework for Determining Critical Success Factors Influencing Construction Vusiness Performance. Built Environment Research School of Engineering and the Built Environment University of Wolverhampton. Wulfruna Street WV1 1SB $\mathrm{Uk}$

[19] Wieseltier, L. (2006). Alms and the man. New Republic, 235(15), 34. https://doi.org/10.1016/j.giq.2013.05.018

[20] Yun, S., Jung, W., Heon, S., \& Park, H. (2015). critical organizational success factors for public private partnership projects - a comparison of solicited and unsolicited proposals, 21(2), 131-143. https://doi.org/10.3846/13923730.2013.802 $\underline{715}$

[21] Cui, C., Liu, Y., Hope, A., \& Wang, J. (2018). ScienceDirect Review of studies on the public - private partnerships (PPP) for infrastructure projects. International Journal of Project Management, 36(5), 773794.

https://doi.org/10.1016/j.ijproman.2018.03. $\underline{004}$

[22] Yang, J., Shen, G. Q., Ho, M., Drew, D. S., \& Chan, A. P. C. (2009). Exploring Critical Success Factors for Stakeholder Management in Construction Projects, 15(4), 337-348. https://doi.org/10.3846/13923730.2009.15.337-348

[23] Regan, M., Smith, J., \& Love, P. E. D. (2017). Financing of public private partnerships: Transactional evidence from Australian toll roads. Case Studies on Transport Policy, 5(2), 267-278. https://doi.org/10.1016/j.cstp.2017.01.003

[24] Kassim, P. S. J. (2011). Objectives, success and failure factors of housing public e private partnerships in Malaysia. Habitat International, 35(1), 150-157. https://doi.org/10.1016/j.habitatint.2010.06. $\underline{005}$ 